\title{
The Satyagraha against diabetes
}

\author{
Sanjay Kalra, Maanash P. Baruah ${ }^{1}$, Banshi Saboo ${ }^{2}$ \\ Department of Endocrinology, Bharti Hospital Eु BRIDE, Karnal, Haryana, ${ }^{1}$ Department of Endocrinology, Excel Hospitals, Guwahati, Assam, \\ ${ }^{2}$ Department of Medicine, Dia Care, Ahmedabad, Gujarat, India
}

\section{A B S T R A C T}

This communication discusses Gandhian thought, i.e, the philosophy propounded by Mahatma Gandhi, and its relevance to modern diabetes care. The authors call for a 'righteous movement' against diabetes, including individual and community-based efforts to minimize its impact. They list various useful suggestions which are concordant with Gandhian thought, and suggest interventions which the Mahatma would have supported in the fight against diabetes. Ideas and thoughts published by him are cited to back these suggestions.

Key words: Diabetes management, diabetes prevention, India, Mahatma Gandhi, obesity

\section{INTRODUCTION}

Mahatma Gandhi, also known as Father of the Nation, is one of the most influential Indians of all times. His thoughts and philosophies continue to shape modern Indian polity, and his achievements are remembered with respect even today, 66 years after his death. A multifaceted personality, his thoughts, words and actions provide much needed motivation to millions of people in India and beyond.

The word 'satyagraha' was used to describe a way of life meant to achieve social transformation. Defined by him as 'pursuit of truth by non-violent means, including voluntarily imposed self suffering, ${ }^{,[1]}$ satyagraha was said to have universal applicability in time, situations and populations. The term satyagraha is used to refer to popular, mass-based movements against evil, which seek to achieve social justice or other beneficial outcomes.

Would satyagraha be applicable to the modern diabetes pandemic? Would Mahatma have used the techniques of satyagraha to prevent, and fight, diabetes? Would he

\begin{tabular}{|l|l|}
\hline \multicolumn{2}{|c|}{ Access this article online } \\
\hline Quick Response Code: & Website: \\
\hline & www.joshd.net \\
\cline { 2 - 3 } & \\
\hline 口. & \\
\hline
\end{tabular}

have given priority to diabetes care, keeping in mind the multiple responsibilities and activities fighting for his attention? What else would he have done to limit the spread of diabetes? This article hypothesizes answers to these questions, based upon the writings of Mahatma Gandhi, and his biographies. ${ }^{[2-5]}$

\section{IMPORTANCE OF DIABETES}

Some of the problems that the world faces today are similar to those of Mahatma Gandhi's time. Poverty, malnutrition, and health issues are as relevant today as they were half a century ago. The character of health issues, however, has changed markedly during this time.

Diseases such as the plague and polio, which Gandhi was familiar with, have been controlled. In their place have emerged chronic lifestyle conditions such as diabetes. The global impact of diabetes, which has emerged as a major public health, as well as economic, problem cannot be underestimated. The Mahatma would therefore certainly have focused his attention on fighting the diabetes epidemic.

Mahatma Gandhi believed in the concept of trusteeship. He felt that man is a trustee of his body, with a pre-ordained duty to care for it. ${ }^{[2]}$ Without a healthy body, one could not have a healthy mind, or serve the nation properly.

Mahatma Gandhi was an ardent advocate for health. He studied both theoretical and practical aspects of health and nutrition, and penned a book entitled. The Key to 
Health. ${ }^{[3]}$ Amongst the eleven wows (Mangal Prabhat) ${ }^{[4]}$ that he requested inmates of his Ashram to take was 'control over palate.' He was a firm believer in the maxim 'eat to live, do not live to eat.' Had he been alive today, he would certainly have taken the diabetes epidemic headon, experimenting upon himself, and practicing dietary control, before advising others.

\section{GANDHIAN LIFESTYLE}

Gandhi would have launched a satyagraha against diabetes a search for the truth, and for solutions which are acceptable to all. He would have studied the issue in detail, and prepared a comprehensive character of demands to achieve holistic health. This would have been concordant with his definition of health: A state characterized by physical fitness, along with harmony of mind and senses.

Gandhi exhorted satyagrahis (soldiers of satyagraha) to fight evil, not the evil- doer. In diabetes, he would have asked the community to tackle diabetes, without discriminating against people with diabetes.

Gandhi would certainly have led a movement in favor of healthy lifestyle. His idea of healthy food is well documented: He proposed a balanced vegetarian diet with limited free sugars and cooking oil, sourced from local farms which use organic methods of growing crops.

Hewould probably have spoken out against the consumption of calorie-dense processed foods, and requested students and other followers to take oaths promising not to take 'foreign-made' or unhealthy foods. This would have been a perfect corollary to his other injunction: Control over the palate, and avoidance of intoxicants. Gandhi would also have taken this opportunity to propound the virtues of vegetarianism. In his writings, he had listed nutritional, scientific, moral, hygienic and economical reasons in favor of a vegetarian diet: These would have been highlighted. ${ }^{[5]}$

Mahatma Gandhi also supported the concept of breadlabor, i.e., earning one's keep through labor. Though not a strong supporter of organized sports, he would have suggested daily physical activity in the form of spinning (Khadi) or involvement on other village industries, to maintain metabolic health. This would have been similar to the evidence-supported concept of community exercise. ${ }^{[6]}$

\section{GANDHIAN DIABETES COUNSELLING}

The rules listed by him for the conduct of satyagraha ${ }^{[1]}$ are particularly appropriate for a person-centered style of diabetes counseling.
Just as taught by Mahatma Gandhi, one should study the issue (diabetes, in this case), and ensure self-reliance before starting satyagraha (the war against diabetes). The expectations from diabetes care should be rational, while explaining all possible courses of action to people with diabetes. The counselor should trust people with diabetes in their care (and vice versa), and aim to achieve consensus building (shared decision making) by nonviolent, pure means (without using intimidation or creating fear). Diabetes counselors should utilize open, straightforward techniques in order to find a position acceptable to all. Since there is no predetermined end to a 'satyagrahic' diabetes counseling, e.g., the use of a particular investigation or management strategy, there is no question of defeat for any participant. A satyagrahi diabetes care professional never assumes that he knows everything, or is 'always right': He strives to understand the whole truth. This is true of every diabetes care providerour professional journey is one of continuous search for excellence.

It is also true of diabetology as a science: Our knowledge is constantly evolving (for the better), and so is our practice. Our understanding of the fact that we still have many facets of diabetes to discover and unravel has also grown in recent years. The diabetes researcher's philosophy, in this way, therefore, is similar to that of a satyagrahi.

\section{GANDHIAN SOCIAL TRANSFORMATION}

The diabetes satyagraha, as visualized by the Mahatma, would extend far beyond the confines of clinics and hospitals. He would have involved the entire community or society, asking them to consume healthy foods, in moderate quantities, and avoid diabetes-unfriendly calorie rich foods, in solidarity with people with diabetes. He would also have requested food manufacturers to voluntarily refrain from producing and selling unhealthy foods, or reduce the content of free sugars, fats oils, salt and condiments.

Physical activity would be encouraged by participation in village industries and farming. The satyagraha against diabetes would also provide for stress management, perhaps through yoga, or meditation, or recreation booths.

\section{GANDHIAN DIABETES MANAGEMENT}

Mahatma Gandhi repeatedly mentioned the need for nonviolence to his satyagrahis: Non-violence in word, 
thought, and deed; by choice, not by compulsion. ${ }^{[7]}$ This should be remembered by all diabetes care professionals: A few words of empathy(diabetes therapy by the ear), ${ }^{[8]}$ simple actions to create diabetes- friendly society, and choice of safe drugs with minimal chances of hypoglycemia and weight gain are what Mahatma Gandhi would have expected from us.

Purity of means was a concept promoted by Gandhi. He felt that means determined the end. Though one did not have control over the final end, one could control the means that one utilized to achieve a particular goal. From a diabetes perspective, reaching a particular $\mathrm{HbA1c}$ is less important than ensuring that safe, welltolerated drug is utilized in diabetes management to do so. Gandhi propagated the use of appropriate technology, in a manner which would not dehumanize people. The use of appropriate technology, including modern drugs, insulins and delivery devices, to manage diabetes, would have been welcomed by him. However, he would certainly have emphasized lifestyle modification as the treatment of choice, and would perhaps have criticized current trends towards drug therapy in place of nonpharmacological action.

\section{CONCLUSION}

Gandhian thought provides an interesting, and hopefully effective counterfoil to the diabetes pandemic. Perhaps the information contained in this editorial can serve as inspiration for a worldwide comprehensive, concerned fight against diabetes. Gandhi's philosophy can also be used as a motivating factor for people with diabetes, family members, and health care professionals, who believe in his ideals.

The last century saw Mahatma Gandhi lead many satyagrahas or movements against socio-political evils. Perhaps we can honor his memory by successfully executing a satyagraha against diabetes creating a way of life which aims to achieve optimal, holistic, health.

\section{REFERENCES}

1. The Story of My Experiments with Truth. Available from: http:// www.mkgandhi.org/autobio/autobio.htm. [Last accessed on 2014 Aug 1].

2. Trusteeship. Available from: http://www.mkgandhi.org/ trusteeship/trusteeship.htm. [Last accessed on 2014 Aug 1].

3. Key to Health. Available from: http://www.mkgandhi.org/health/ keytohealth/index.htm. [Last accessed on 2014 Aug 1].

4. From Yeravda Mandir (Ashram Utterances). Available from: http:// www.mkgandhi.org/ebks/yeravda.pdf. [Last accessed on 2014 Aug 1].

5. The Moral Basis of Vegetarianism. Available from: http:// www.mkgandhi.org/ebks/moralbasis_vegetarianism.pdf. [Last accessed on 2014 Aug 1].

6. Dalleck LC, Van Guilder GP, Richardson TB, Bredle DL, Janot JM. A community-based exercise intervention transitions metabolically abnormal obese adults to a metabolically healthy obese phenotype. Diabetes Metab Syndr Obes: Targets and Therapy 2014;7:369-80.

7. Gandhi: A life. Available from: http://www.mkgandhi.org/ebks/ gandhi_a_life.pdf. [Last accessed on 2014 Aug 1].

8. Kalra S, Unnikrishnan AG, Baruah MP. Diabetes therapy by the ear. Indian J Endocrinol Metab 2013;17(Suppl 3):S596-8.

How to cite this article: Kalra S, Baruah MP, Saboo B. The Satyagraha against diabetes. J Soc Health Diabetes 2015;3:1-3.

Source of Support: Nil. Conflict of Interest: None declared. 